\title{
League of Nations Publications in the Present Emergency
}

Miss Signor is librarian in history and political science, University of Illinois Library, Urbana.

T T IS IMPORTANT, in the light of present1 day affairs, for one to review the achievements of the League of Nations during the past twenty years in order to evaluate again the ideals and principles of international cooperation embodied in all its undertakings. The publications of the League of Nations are important sources of information for study and research because of their international aspect, the wide field of subjects included, and their high standards of accuracy and thoroughness. Many people think of the League of Nations only as a political unit, focusing their attention on its several failures and disregarding its constructive and humanitarian activities.

In spite of the present war and the rapid change of governments, the technical organizations in the League of Nations have been able to carry on a fair amount of research and publication. The Publication Department of the League of Nations recently announced the regular continuance of two periodicals, Monthly Bulletin of Statistics and Weekly Epidemiological Record. In addition, the Treaty Series will be continued and documents will be issued by the Economic and Financial

1 The information in this article is as of June 1942.
Section, Social Section, Disarmament Section, and Opium Section.

The chaotic conditions in Europe have made it necessary to distribute the work of the League of Nations among various centers. The Political Section was kept at Geneva; the Economic, Financial, and Transit sections were centered at Princeton University; the Opium Section was transferred to Washington; and the International Labour Office, whose work is closely allied with that of the league, was removed to McGill University, Montreal. Difficulties arose over the transportation of French officials of the International Labour Office to a belligerent country, making it necessary to transfer some of the work of this office to Washington. The publications of the Permanent Court of International Justice have been suspended indefinitely. The offices of the World Court were closed when the Peace Palace at the Hague was bombed. The International Institute of Intellectual Cooperation at Paris is closed and no publications are being issued.

Because of the uncertainty of publication and the limited number of copies being printed, libraries, particularly those binding sets by publication number, would be well advised to scrutinize very carefully global subscriptions to League of Nations' documents to insure receipt of all publications. The Monthly Bulletin of Statistics and weekly Epidemiological Record sub- 
scriptions are invoiced separately from global orders and from other corresponding orders; other publications have been placed on a continuation order basis, whereby documents are supplied as they are published and billed at the end of the year. League of Nations publications may be secured through the International Document Service, Columbia University Press, New York City.

American interest in the wartime activities of the League of Nations was first made evident by the organization of a national committee of eminent Americans to aid and preserve the League of Nations nonpolitical work. This was followed by a joint invitation from Princeton University, the Institute for Advanced Study, and the Rockefeller Institute of Medical Research to the League of Nations to establish its technical services at Princeton University for the duration of the emergency. This invitation was accepted on behalf of the Economic, Financial, and Transit sections, and in August 1940 the director and part of their staff were sent to Princeton University. Certain members of the sections were left in Geneva to follow the economic developments within Europe in order to supply data for continuing the statistical publications. Much of the present work of this department has been made possible by a grant of fifty thousand dollars from the Rockefeller Foundation, to be used during the years 1941 and 1942.

\section{ECONOMIC AND FINANCIAL SECTION}

\section{Economic Intelligence Service-Statistical} Documents

The Economic and Financial Section of the League of Nations has doubtless made its greatest contribution to research in the field of comparative statistics. The Economic Intelligence Service which is connected with the Economic and Financial Section is responsible for some of the most important statistical data published by this section. This service was founded as a result of the Brussels Conference of 1920. Its immediate object was to coordinate and centralize information made public by national administrators on subjects of economic importance. It has published regularly so much economic and financial information that it has now become one of the most valuable and highly appreciated sources of financial and economic documentation. Previously it published in the course of the year three strictly statistical documents and a series of studies dealing with different aspects of the world economic situation. Although economic statistics and financial information have been greatly curtailed, the league is making every effort to continue the work of the Economic Intelligence Service owing to the fact that new economic trends which are becoming more evident during the war period are likely to become the bases for formulating postwar economic policies. With this in mind the league has decided to continue two strictly statistical publications, the Monthly Bulletin of Statistics and the Statistical Yearbook; the World Economic Survey and a number of special studies are also being published.

The Monthly Bulletin of Statistics, which has been issued at Geneva monthly since July 1919 , is continuing without interruption. This gives the most recent figures on the economic and financial development of the countries of the world based on official information specially supplied each month. With September 1940 copies were also printed on thin paper to 
be sent by airmail for the league's mission in Princeton.

While the Monthly Bulletin of Statistics gives a current indication of the status of economic conditions throughout the world, the Statistical Yearbook of the League of Nations is restricted to an intensive study of statistical data for a selected number of subjects of current importance. The latest issue of the Statistical Yearbook gives statistics up to the end of 1939 and in some cases also for the first half of 1940 .

\section{Economic Intelligence Service-Special Studies}

While the statistical documents described above are made up largely of statistical tables from which one may draw his own conclusions, the World Economic Studies are analyses of world conditions drawn from information collected from all parts of the world, which were formerly issued in separate memoranda. Available material on such subjects as world trade, production and prices, banking, and public finance, is no longer complete enough to justify the publication of the separate memoranda. Instead, the Economic Intelligence Service has issued a $W$ orld $E$ conomic Survey covering the period from the autumn of 1939 to the summer of I94I. Previous issues of the World Economic Survey (1932-39) consisted of a general analysis of the organization of industry and commerce in the world as a whole, based mainly on the results of the various studies carried on by the Economic Intelligence Service supplemented by the information drawn from other sources, such as the International Labour Office. The World Economic Survey 1939-4I, which was published at Princeton by the uni- versity press in 194I, is a survey of the world at war. It deals with the problems of war economy in the countries at war as well as the reverberations of the war throughout the world. The first chapters deal with the means by which the change from peace to war economy was effected in the different countries, while the later chapters deal with the effect of these changes on various forms of economic activity.

Raw Materials and Foodstuffs was published at Geneva in January I940. It is a study of the sources of supply of all the more important raw materials and foodstuffs arranged by country for the years I935 and 1938. The main tables are so arranged that by consulting a single table one may see the countries which produce each commodity and the amount of production for each country. It is an excellent reference source for those desiring exact information on production and trade in raw materials and foodstuffs.

Because of the reduction of national trade statistics it has been impossible to continue the publication, Review of $W$ orld Trade, which appeared annually for the years 1933-38. It has been replaced by a special study, Europe's Trade, published in Geneva in the spring of 194I. This is an analysis of the part played by Europe in the trade of the world before the outbreak of the present war and a consideration of how far Europe is dependent upon external markets and to what extent external markets are dependent upon her. It is the plan of the Economic Intelligence Service to follow up this analysis with a companion volume covering the trade of the rest of the world.

Since I93I the Economic Intelligence Service has published an annual memoran- 
dum on commercial banks, under varying titles. In 1937 under the title Money and Banking a two-volume series was published: v. I. Monetary Review, v. 2. Commercial Banks. It was decided with the I939-40 issue of Money and Banking to discontinue the second volume but to continue the Monetary Review. The latest number was published in Geneva in 1940 and covers the period September 1939-40. It is a study of the far-reaching measures adopted by various governments for the control and operation of the banking system since the outbreak of the war. A brief introductory note precedes the review, which summarizes the monetary situation -from the appearance of the preceding issue of the Monetary Review in the spring of 1939 to September 1939.

\section{The Fiscal Committee}

Since its organization in 1929 the Fiscal Committee has had as its main objective the formulation of treaties and conventions to prevent double taxation in the fields of income and property taxes. In spite of the present war situation the Fiscal Committee has held two meetings, one at the Hague in April 1940 and the second at Mexico City, June r940. The second meeting was particularly significant since it was the outcome of a request made in I 938 to the Fiscal Committee by the Mexican government that a study be made of certain principles of taxation which would be helpful to Latin American countries which were in the process of developing their tax systems. Because war had spread all over Europe at this time, the Mexican government extended an invitation to the conference to convene at Mexico City. Representatives from Argentina, Brazil, Peru, Venezuela, Mexico, Canada, and the United States were present to comment on the preliminary studies submitted. The important result of the meeting was the adoption of a draft for a model convention for the prevention of double taxation in the field of income and property taxes, which brings up to date the model conventions framed by the Conference of Governmental Experts of 1928. It is highly important that the work of the Fiscal Committee be continued since the question of double taxation will undoubtedly be an important problem of the postwar period, especially in its relation to inter-American trade.

\section{HEALTH SECTION}

\section{Epidemics}

The successful work of the League of Nations in the control of infectious diseases is due largely to the Epidemiological Intelligence Service. The work of this service is so important that at the present time it is receiving support both from neutral countries and from countries at war. Since January I930 it has published the Weekly Epidemiological Record regularly at Geneva. This periodical supplies prompt information on the prevalence of contagious disease which at the time constitute an international danger. Until the time of the Japanese occupation, the most important part of the service was centered at Singapore, to which place more than 180 ports in the surrounding area sent in cable messages weekly or even more frequently concerning the occurrence of epidemic disease. In normal times the information received at the Singapore bureau was analyzed and broadcast by ten wireless stations to every health officer, every captain of a ship, and every airplane pilot in the area from Panama on the East, 
Suez on the West, and Vladivostok on the North, so that they might know to what extent disease prevailed and what quarantine measures to adopt. Before the fall of Singapore the officers in charge of this service were safely transferred to Sydney, but at the present time it is not known whether it will prove possible to reestablish the bureau in another center. The information assembled at Singapore was published currently under the title: Weekly Fascicules: Epidemiological Intelligence Received by the Eastern Bureau. No. 878 of January 8,1942 , is the latest that has been seen. A similar service exists at Geneva for information concerning epidemics in Europe, but so far there has been less need, for rapid service than in the Far East. With the migrations of peoples and movements of troops resulting from the war the Epidemiological Service has followed very closely all developments of epidemics of infectious diseases and has taken every precaution to prevent their spread.

\section{Biological Standardization}

In 1924 the Health Committee of the League of Nations set up a Permanent Commission on Biological Standardization to establish international standards for the use of sera, glandular preparations, vitamins, and other remedies, the activity of which can be measured only by biological methods. By 1935 the commission had made available international standards and units for most of the important drugs which are biologically tested. Since in wartime the standards of serum content are so important, the Copenhagen Serological Institute together with the London Institute have made a great effort to continue the normal distribution of standards of sera, vitamins, hormones, and certain other medicaments to most countries.

The Bulletin of the Health Organization was issued quarterly from March I 932 to December 1936 and bimonthly from February 1937 to December 1939 at Geneva. It includes material brought together by the Health Organization of the league on such subjects as epidemics, malaria, biological standardization, housing, nutrition, cancer, tuberculosis, and rabies. For the information of those interested in medical subjects it includes articles by leading authorities in the field of health and social medicine.

SOCIAL SECTION

\section{Child Welfare}

In 1934 the Assembly of the League of Nations established the Child Welfare Information Center to centralize information relating to child welfare. For the last three years it has collected and classified information concerning child welfare and has issued each year a Summary of the Legislative and Administrative Series of Documents of the Child Welfare Information Center. The last issue was published at Geneva in January I940 and as in previous years it summarizes documents relating to maternal and child welfare and social service. The information center also published an Annual Report on Child Welfare which aims to show the progress made in child welfare in the various countries from the legislative and administrative points of view. This includes either a summary or the complete text of important laws which have been put in force for the protection of families and children and to combat prostitution. The latest issue was published at Geneva in March I940.

The Advisory Committee on Social 
Questions issues annually a Summary of Annual Reports on Traffic in $W$ omen and Children. This consists of summaries of reports made by the governments of various countries in reply to questionnaires on social questions issued by the advisory committee. The Summary for 1939-40 was published at Geneva in May $194 \mathrm{I}$.

\section{OPIUM SECTION}

\section{Drug Traffic}

At meetings held in Geneva in May I940 the three international organizations dealing with the drug traffic, namely, the Advisory Committee on Traffic in Opium and Dangerous Drugs, the Permanent Central Opium Board, and the Drug Supervisory Body, decided to continue their technical work during the war, since past experience had shown that need for drug control increased rather than diminished under war conditions.

The Advisory Committee on Traffic in Opium and Other Dangerous Drugs, which met for its twenty-fifth session on May I3-17, 1940, included delegations from thirteen out of the twenty-three government members. Special emphasis was placed on the importance of cooperation of the governments with the international organizations in order to prevent the extension of illicit drug traffic and increased drug addiction resulting from the war. The Minutes of this meeting were published in Geneva, December I940.

The Permanent Central Opium Board is concerned with the control of trade in narcotic drugs, based on statistics supplied by the various governments. In January I 94 I it issued the regular Annual Report on the Statistics of Narcotics for 1939 and the Work of the Board during r 940. This report which is based on statistics received from fifty countries and from ninety to one hundred dependencies, is mainly statistical as war conditions have made it necessary to omit analysis and comment.

The Drug Supervisory Body is the organization which determines the lawful amount of drugs that may be manufactured and consumed throughout the world during a given year. It examines the estimates of the narcotic requirements submitted by the various governments and draws up estimates for countries for which estimates have not been submitted. Its most recent statement, Estimated World Requirements of Dangerous Drugs in 1942, was published in Geneva, December I94I.

In the spring of $194 \mathrm{I}$, owing to difficulties of communication with certain countries, a branch office of the Permanent Central Opium Board and the Drug Supervisory Body was established in Washington where the control of drug traffic will be centered during the present war.

\section{Refugees}

By a resolution passed by the Assembly of the League of Nations in September I 938 the Nansen International Office for Refugees ceased its activities in December 1938 and a high commissioner of the League of Nations was appointed to deal with refugees. The high commissioner issued an Annual Report in July 1939, a Supplementary Report, October 1939, and an Intermediate Report, April 1940. His latest report which is dated January I $94 \mathrm{I}$, as in the case of previous ones, deals, not only with the humanitarian aspect of the refugee problem, but with the provisions made for the legal protection of refugees and their emigration and settlement. Much of the information included is based 
on personal interviews of the high commissioner with representatives of the governments and private organizations assisting in the work.

\section{Treaty Series}

About two hundred volumes of this series have been published since September 1920. The series includes treaties of peace, treaties of commerce, international conventions, renewals and denunciation of treaties, and so forth. The texts of the treaties are in their original language with an English and French translation added when the text is not in one of these two languages. It is the intention of the league to continue the publication of this series as long as funds permit.

\section{Library}

The Monthly List of Selected Articles resumed publication in January $194 \mathrm{I}$, after an interruption from May to December 1940. At present it is not published each month but appears in combined issues at various intervals. It is a selected list of articles on political, legal, economic, financial, and social questions of the day compiled from abstracts made of about eight hundred periodicals appearing in all parts of the world. At the present time there is no other such publication being issued in Europe.

\section{Recent Publications on Present Activities of the League of Nations}

The purpose of the foregoing article has been to list and describe the services and publications of the league which have continued during the present World War. The articles in the following bibliography are cited as a useful means of current orientation on the actual work of this vast organization.

Geneva Research Center. "Geneva as an International Centre." (Its Information Bulletin v. 3, no. I, 1940)

Hambro, C. J. "League Agencies Functioning." New York Times, Nov. 3, 1941, p. 6.

Mary E. Woolley Committee. Press Release. New York, June I, 1940.

Sweetser, Arthur. "Correcting a False Impression about the League." New York Times, Nov. 23, 194I, Sec. 4, p. 4.

Sweetser, Arthur. "League Work in America." Changing World 12:7,12, Sept. I940.

Sweetser, Arthur. "The United States and World Organization in 1940." (Geneva Studies, v. I I, no. 8, Dec. I940) Reprinted in International Conciliation, 1941, p. 603I3.

Woolley, Mary E. "Must These Things Die?" Changing World I $2: 9$, June 1940. 